\title{
Susceptibility of Fourteen New Cucurbit Species to Gummy Stem Blight Caused by Stagonosporopsis citrulli Under Field Conditions
}

\author{
Gabriel Rennberger ${ }^{\dagger}$ and Anthony P. Keinath, Clemson University, Coastal Research and Education Center, Charleston, SC 29414
}

\begin{abstract}
At least 24 species of cucurbits from 13 genera are known to be susceptible to gummy stem blight, caused by three species of Stagonosporopsis. Cankers that are formed on crowns and stems play an important role in the disease cycle and the survival of the pathogen. Fourteen cucurbit species of unknown susceptibility representing 12 genera, four taxonomic tribes, and four geographic origins were inoculated with Stagonosporopsis citrulli in Charleston, SC, in spring 2015, spring 2016, and fall 2016 to evaluate their level of susceptibility to gummy stem blight and the ability of the pathogen to reproduce on crown cankers. An additional species, Cucumis melo, was included as a reference due to its known high susceptibility. Data sets of area under the disease progress curve (AUDPC) for foliar severity and crown cankers, final percentage of diseased leaf area, final percentage of plants with cankers, final percentage of plants with fruiting bodies, and rates of increase in canker incidence were analyzed to evaluate susceptibility. Results were similar for datasets of AUDPC and final ratings but there were more differences for AUDPC. In all experiments, Apodanthera sagittifolia, Ecballium elaterium, and Kedrostis leloja were at least as susceptible to foliar blight as the reference $C$. melo. $K$. leloja was as susceptible to crown cankers as $C$. melo in all experiments and A. sagittifolia and E. elaterium were among the species most

susceptible to crown cankers in two experiments. Coccinia grandis was highly resistant to gummy stem blight and had a few cankers only in fall 2016. Sicana odorifera and Zehneria pallidinervia also consistently grouped with the most resistant species. Incidence of crown cankers on Cucumis melo and $K$. leloja increased at the fastest rate of all species in all experiments and had, along with E. elaterium, the highest incidence of crowns with fruiting bodies. In general, the most susceptible species also were most suitable for reproduction of the pathogen and had the fastest disease progression. The tribes Benincaseae and Cucurbiteae had consistently lower levels of foliar blight than Bryonieae and Coniandreae. The tribe Benincaseae had a consistently lower AUDPC for canker incidence than Bryonieae and Coniandreae. The species originating from Europe (E. elaterium) was consistently most susceptible to both symptoms, while African species grouped with the least susceptible species in all experiments. To the best of our knowledge, this is the first report of susceptibility to gummy stem blight of 14 species and the first report of susceptibility of the cucurbit tribes Coniandreae and Gomphogyneae. This expands the host range of Stagonosporopsis citrulli to 37 species representing 21 genera and seven tribes in the family Cucurbitaceae. This study demonstrates the importance of crown cankers as reproductive sites for $S$. citrulli.
\end{abstract}

The plant family Cucurbitaceae comprises about 960 species in 115 genera that are mainly tropical and subtropical tendril-bearing climbers. Approximately 50 genera in the family contain only one species (Kocyan et al. 2007). Its center of origin is Asia, from which cucurbits spread around the world via long-distance dispersal events. The majority of species (40\%) is endemic to the American continent, $28 \%$ occur in Africa, and $26 \%$ in Asia. The remaining species are found in Australia (2\%) and Europe (1\%) (Schaefer et al. 2009). Cucurbitaceae is one of the most genetically diverse families in the plant kingdom and among the most important ones for human utilization, even though only about $0.5 \%$ of the species are used commercially (Robinson and Decker-Walters 1997). In 2014, the annual worldwide production of the main cucurbit crops-cucumber, melon, gourd, pumpkin, squash, and watermelon-was $240.81 \times 10^{6}$ tons, of which $3.96 \times 10^{6}$ tons were produced in the United States. The total worldwide vegetable production in the same year, $1,169.45 \times 10^{6}$ tons, puts these numbers in perspective (FAO 2017) and illustrates the importance of cucurbits as commercial crops (Kocyan et al. 2007; Zhang et al. 2006).

Gummy stem blight (GSB), caused by three morphologically indistinguishable but genetically distinct species of Stagonosporopsis (Stewart et al. 2015), is a major disease of cucurbits with a worldwide distribution that occurs in all cucurbit-producing areas (Keinath

${ }^{\dagger}$ Corresponding author: G. Rennberger; E-mail: gabrielrennberger@gmail.com

Funding: This material is based on upon work supported by National Institute of Food and Agriculture, U.S. Department of Agriculture under project number SC-1700536. The South Carolina Agricultural Society supplied the Thomas Heyward Jr. Graduate Fellowship to G. Rennberger. Technical Contribution Number 6609 of the Clemson University Experiment Station.

Accepted for publication 1 February 2018.

@ 2018 The American Phytopathological Society
2011). Two of the three species, $S$. citrulli and $S$. cucurbitacearum (syn. Didymella bryoniae), are host specific to cucurbits, whereas S. caricae also infects papaya (Carica papaya) (Stewart et al. 2015). The most common and widespread species, $S$. citrulli, is also the predominant species in the southeastern United States (Brewer et al. 2015; Stewart et al. 2015). Symptoms of GSB are circular, tan to brown water-soaked lesions on cotyledons, leaves, petioles, hypocotyls, and stems. The disease is referred to as black rot on fruit, which can have variable symptoms depending on the affected fruit. If the cortical tissue of stems and crowns are infected, cankers can develop, which may lead to the production of a reddish-brown gummy exudate (Chiu and Walker 1949; Grossenbacher 1909; Keinath 2008, 2017; Zitter 2017). Cankers are commonly formed on crowns and stems of pumpkin (Cucurbita pepo), squash (C. maxima), bottle gourd (Lagenaria siceraria), cucumber (Cucumis sativus), watermelon (Citrullus lanatus), and muskmelon (Cucumis melo) (Chiu and Walker 1949; Keinath 2008, 2014a; Schenck 1968). High levels of resistance to crown cankers were found in Cucurbita moschata and C. pepo 'Gray Zucchini' (Chiu and Walker 1949; Grossenbacher 1909; Keinath 2014a).

At least 24 species of cucurbits from 13 genera are known to be susceptible to GSB (Jiang et al. 2015; Keinath 2011). Among these are all major cucurbit crops. To this day, no commercially acceptable cultivars of any cucurbit crop with resistance to GSB are available (Keinath 2017). Susceptibility to GSB varies greatly within the family Cucurbitaceae. Generally, Citrullus lanatus (watermelon) and Cucumis melo (melon) are the most susceptible species (Chiu and Walker 1949; dos Santos et al. 2009; Keinath 2014a). Under conducive conditions, yield losses in cantaloupe can reach $100 \%$ and average above $40 \%$ in watermelon (Keinath and Duthie 1998; Zhang et al. 1999). In previous studies where the susceptibility of various cucurbits to GSB was compared, Cucurbita spp. were consistently less susceptible than watermelon and melon (Bala and Hosein 1986; Chiu and Walker 1949; dos Santos et al. 2009; Grossenbacher 1909; Keinath 2014a). The only exception to this is the high susceptibility of C. argyrosperma reported by Keinath (2014a). Apart from 
a study by Wehner and St. Amand (1993), who tested six species of Cucumis, no experiments to test cucurbits for their susceptibility to GSB have included minor crops or wild species. Because of the high potential to find resistance in wild, untested cucurbits, there is a need to investigate these unstudied plant species.

The survival of $S$. citrulli in colonized cucurbit debris, which acts as a source of inoculum for subsequent crops, was investigated in several studies (Chiu and Walker 1949; Keinath 2002, 2008; Sitterly 1969; Van Steekelenburg 1983). On buried, naturally infected watermelon vines, $S$. citrulli survived for up to 30 weeks, while the survival time on buried muskmelon crowns was extended to 103 weeks (Keinath 2002, 2008). The crown of a cucurbit plant can be described as the part where the short main stem divides into two or more primary vines. It is the thickest and one of the most lignified parts of the plant (Keinath 2008). Therefore, crowns decompose slowly and are of particular importance as a reservoir for the survival of inoculum into a consecutive crop. The difference in survival time on watermelon vines as opposed to muskmelon crowns illustrates this aspect (Keinath 2002, 2008).

As a homothallic fungus, $S$. citrulli produces both pycnidia (asexual fruiting bodies) and pseudothecia (sexual fruiting bodies) on suitable hosts (Keinath 2014b; Punithalingam and Holliday 1972). The requirements for the formation of fruiting bodies are free moisture and temperatures of $>5^{\circ} \mathrm{C}$ (Van Steekelenburg 1983). When these conditions are met, the fungus produces pycnidia and pseudothecia on cucurbit debris remaining on fields, which subsequently release the inoculum for a new disease cycle (Chiu and Walker 1949; Keinath 2002; Schenck 1968). The two spore types produced by pycnidia and pseudothecia play different roles in the epidemiology of the pathogen. Although conidia released from pycnidia mainly spread from plant to plant, ascospores released from pseudothecia can act as primary inoculum and as units of further dispersal (Schenck 1968). Reports of fruiting bodies of S. citrulli on crowns and stems are scarce. In the first account of GSB on watermelon, Chester (1891) reported pycnidia on vines. Later, Schenck (1968) described both types of fruiting bodies specifically on crowns of watermelon as lesions that started on the cotyledons of seedlings and spread to the hypocotyl and crown. After inoculation experiments, Grossenbacher (1909) and Jensen et al. (2011) found both pycnidia and pseudothecia on vines and stems of Cucurbita maxima. The only study that examined the frequency of fruiting bodies on a large selection of cucurbits did not include crowns. Sporulation of the pathogen was reported on leaves, pedicels, peduncles, petioles, tendrils, and vines of nine species from five genera (Keinath 2014b). The formation of cankers and reproduction of $S$. citrulli has not been studied on minor crop and wild cucurbit species.

The objectives of this study were to (i) characterize the level of susceptibility of 14 species of cucurbits to foliar blight and crown cankers caused by $S$. citrulli, (ii) compare the relative susceptibility of cucurbits in different geographic origins and tribes within the family Cucurbitaceae, (iii) compare the rate of canker development among the species, and (iv) compare the reproduction of the pathogen on different hosts and test whether more susceptible species also are more suitable for reproduction of the pathogen. The species included in this study were chosen to represent the taxonomic and geographic diversity of the cucurbit family. Species initially considered for inclusion were limited to those with seed readily available commercially.

\section{Materials and Methods}

Field experiments. Three experiments were conducted at the Clemson University Coastal Research and Education Center in Charleston, SC. The experiments were done in spring 2015, spring 2016, and fall 2016. A different field was used for each experiment. The field used in spring 2015 was cropped to muskmelon the previous spring, followed by a cover crop of rye and clover, which was disked into the soil 3 months before transplanting. In the field used in spring 2016, sunflower was grown the previous year, followed by a cover crop of crimson clover. The cover crop was disked 3 months before transplanting. The field used in fall 2016 was cropped to corn and sorghum in the spring of the same year and disked twice after mowing the sorghum. Fourteen species of cucurbits were selected to represent 12 genera and five tribes originating from six different geographical regions (Table 1). In 2015, all species were seeded at the same time. In 2016, seeding was staggered based on germination in 2015 to achieve similar developmental stages of species. Coccinia grandis, Cucumis anguria, Ecballium elaterium, Gynostemma pentaphyllum, Melothria scabra, and Zehneria pallidinervia were seeded first. Four days after that, Acanthosicyos horridus, Apodanthera sagittifolia, Kedrostis leloja, C. melo 'Athena', and Sicana odorifera were seeded. The last group of species-C. zambianus, Cucurbita digitata, C. ecuadorensis, and L. sphaerica - was seeded 6 days after the second group.

All plots consisted of a single-row raised bed that was $0.9 \mathrm{~m}$ wide on a 3.6-m center. Rows of plastic mulch were arranged in blocks of three, with the middle row remaining unplanted. Beds were covered with white-on-black polyethylene mulch in spring 2015 and fall 2016. In spring 2016, black polyethylene mulch was used. Seedlings were transplanted on 4 May 2015, 26 April 2016, and 11 August 2016. Plots were arranged as a randomized complete block design with four replications and seven plants per plot. In 2015, plots were $8.5 \mathrm{~m}$ long with $1.2-\mathrm{m}$ spacing between plants within the row. Unplanted space between plots within rows was $4.6 \mathrm{~m}$. In 2016, plots were $10.7 \mathrm{~m}$ long, with 9.1 and $6.1 \mathrm{~m}$ of unplanted space between plots in spring and fall, respectively. In 2016, spacing between plants

Table 1. Cucurbit species tested for gummy stem blight susceptibility in the field in South Carolina in three experiments 2015 and 2016

\begin{tabular}{|c|c|c|c|c|c|c|c|}
\hline Genus & Species & Common name & Tribe $^{x}$ & Origin & Cultivated & Native status in the United States ${ }^{y}$ & Seed source \\
\hline Acanthosicyos & horridus & Nara melon & Benincaseae & Africa & Yes & Not native & rarepalmseeds.com \\
\hline Apodanthera & sagittifolia & Argentinian melon & Coniandreae & South America & No & Not native & kcb-samen.ch \\
\hline Coccinia & grandis & Ivy gourd & Benincaseae & Africa & Yes & Invasive & rarepalmseeds.com \\
\hline Cucumis & anguria & Bur gherkin & Benincaseae & Africa & Yes & Invasive & sunshine-seeds.de \\
\hline Cucumis & melo 'Athena' & Cantaloupe & Benincaseae & Africa & Yes & Introduced & siegers.com \\
\hline Cucumis & zambianus & None & Benincaseae & Africa & Yes & Not native & horizonherbs.com \\
\hline Cucurbita & digitata & Fingerleaf gourd & Cucurbitieae & North America & No & Native & horizonherbs.com \\
\hline Cucurbita & ecuadorensis & None & Cucurbitieae & South America & No & Not native & rarepalmseeds.com \\
\hline Ecballium & elaterium & Squirting cucumber & Bryonieae & Europe & Yes & Introduced & horizonherbs.com \\
\hline Gynostemma & pentaphyllum & Jiaogulan & Gomphogyneae & Asia & Yes & Not native & horizonherbs.com \\
\hline Kedrostis & leloja & None & Coniandreae & Africa & No & Not native & kcb-samen.ch \\
\hline Lagenaria & sphaerica & None & Benincaseae & Africa & Yes & Not native & rarepalmseeds.com \\
\hline Melothria & scabra & Mouse melon & Benincaseae & North America & Yes & Not native & sunshine-seeds.de \\
\hline Sicana & odorifera & Casabanana & Cucurbitieae & South America & Yes & Introduced ${ }^{\mathrm{z}}$ & rarepalmseeds.com \\
\hline Zehneria & pallidinervia & Bat wing vine & Benincaseae & Africa & No & Not native & ... \\
\hline
\end{tabular}

${ }^{x}$ Classification based on Schaefer and Renner (2011).

y Based on United States Department of Agriculture (USDA)-Natural Resources Conservation Service (NRCS), https://plants.usda.gov/java/.

${ }^{\mathrm{z}}$ Introduced only in Puerto Rico (USDA-NRCS). 
within plots was adjusted according to the growth habit of the species. In spring 2016, Cucumis zambianus and Coccinia grandis were spaced $1.5 \mathrm{~m}$ apart and all other species $1.2 \mathrm{~m}$. In fall 2016, spacing between plants was $0.6 \mathrm{~m}$ for Acanthosicyos horridus and Z. pallidinervia, $1.5 \mathrm{~m}$ for Cucumis anguria and C. zambianus, $0.9 \mathrm{~m}$ for E. elaterium, and $1.2 \mathrm{~m}$ for all other species. In all experiments, weeds, insects, anthracnose, downy mildew, and powdery mildew were managed with recommended pesticides (Keinath et al. 2010).

In all experiments, crowns of all plants were inoculated with a suspension of two isolates of $S$. citrulli that were originally recovered from watermelon in South Carolina (HD10 and W764). Isolates of this species were used because of its local and global distribution. Fungal cultures were grown on quarter-strength potato dextrose agar (QPDA) for 2 weeks with $12 \mathrm{~h}$ of light. Inoculum was harvested by flooding plates with $7 \mathrm{ml}$ of a solution of $0.05 \%$ casein and $0.1 \%$ sucrose (Svedelius 1990) and scraping with sterile microscope slides. In all, 20 plates of each isolate were prepared in 2015 and 30 plates in 2016 . The volume was brought up to $500 \mathrm{ml}$ with additional casein-sucrose solution and blended for $1 \mathrm{~min}$. The blended inoculum suspension was diluted to a volume of 1.3 liter and contained spores and mycelial fragments. Inoculum densities in the three experiments, as determined by plating of serial dilutions on QPDA, were $6.7 \times 10^{6}, 9 \times 10^{6}$, and $6 \times 10^{5} \mathrm{CFU} / \mathrm{ml}$, respectively. Handheld spray bottles were used to apply $3 \mathrm{ml}$ of inoculum suspension on the crowns of all plants. Inoculations were done on 10 June 2015, 15 June 2016, and 8 August 2016 in the evening at 7 to 8 P.M.. The middle unplanted row of the blocks of three rows was used to set up a misting system with overhead, low-pressure, mini-wobbler sprinklers (Senninger Irrigation) to supply additional leaf wetness before inoculation and then throughout the entire duration of the experiments. In spring 2015 and in fall 2016, the misting system was turned on for 15 min prior to inoculation. In spring 2016, heavy rain just prior to inoculation provided optimum conditions and rendered additional misting unnecessary. After inoculation, the misting system was run twice per day for $30 \mathrm{~min}$ at 6 A.M. and 8 P.M. in spring 2015 and 2016. In fall 2016, it was run four times for 15 min at 3 A.M., 6 A.M., 8 P.M., and 12 P.M. due to below-average precipitation.

Severity of GSB on foliage was rated on each third of each plot using a percent scale from 0 to $100 \%$ with $5 \%$ increments, plus $1 \%$ for minor symptoms. In spring 2015 , severity was rated seven times. In spring 2016, severity was rated nine times, of which the first rating was 5 days prior to inoculation because early symptoms of GSB were observed on six species. In fall 2016, severity was rated five times. Four symptomatic leaves were collected from each plot on $10 \mathrm{July}$ 2015, 7 August 2016, and 26 October 2016. One piece of tissue from each collected leaf was surface disinfested for $1 \mathrm{~min}$ in a solution of $0.825 \%$ sodium hypochlorite and transferred to petri dishes with QPDA amended with chloramphenicol at $0.1 \mathrm{~g} /$ liter, streptomycin at $0.1 \mathrm{~g} /$ liter, and mefenoxam (Ridomil Gold SL; Syngenta AG) at $45.3 \mu \mathrm{l} /$ liter to recover the pathogen (Keinath 2008).

Incidence of crown cankers and presence of fruiting bodies of $S$. citrulli was determined by closely examining each crown for symptoms and signs of the pathogen. Crown cankers were counted three, four, and two times in the three field experiments (spring 2015, spring 2016, and fall 2016, respectively). Presence of fruiting bodies of the pathogen was recorded every time, whenever incidence of crown cankers was rated, with the exception that it was omitted the first time canker incidence was determined in 2015. After the last rating in each experiment, four symptomatic crowns were collected from each plot. The pathogen was recovered from two pieces of tissue from each crown as described for leaves.

Statistical analyses. The three severity ratings per plot were averaged together. The area under the disease progress curve (AUDPC) of foliar severity ratings and of crown incidence ratings was calculated with PROC MEANS (version 9.4; SAS Institute Inc.) (Shaner and Finney 1977). Relative AUDPC was calculated by dividing data from each experiment by the corresponding number of days between the first and the last rating. Values for AUDPC of foliar severity in 2015 and fall 2016 were square-root transformed and log transformed in spring 2016. Disease severity data for last ratings were square-root transformed in spring 2015 and spring 2016. Based on residual plots, no transformation was necessary in fall 2016. The effects of species, experiment, and their interaction were included as fixed effects and block within years was included as a random effect in the model used in PROC GLM. When a species-experiment interaction was present, data sets from experiments were compared separately, and the SLICE statement of the LSMEANS option of PROC GLM was used to analyze differences among experiments for each species. Values presented in the tables were back transformed.

Values for AUDPC of crown canker incidence were square-root transformed for 2015 and arcsine square-root transformed for spring 2016. Based on residual plots, no transformation was necessary for fall 2016. The effects of species, experiment, and their interaction were included as fixed effects and block within years was included as a random effect in the model used in PROC GLM. When an interaction was present, data sets from experiments were compared separately, and the SLICE statement of the LSMEANS option of PROC GLM was used to analyze differences among experiments for each species. Values presented in the tables were back transformed. The data of fruiting body incidence based on total number of plants was analyzed in the same manner but only data from 2015 were arcsine square-root transformed.

Because transformations could not correct for nonnormality and inequality of variances for the canker incidence ratings, data were analyzed with PROC CATMOD for categorical data analysis. Using the logit as response function, the proportions of plants with crown cankers were analyzed with the maximum-likelihood method to estimate linear model parameters. Because data sets that contain percentage values of 0 or 100 cannot converge in this procedure, percentage values were replaced with a Bayes estimator with the following formula: $x=(c t+k / r) \times n /(n+k)$, where $x=$ the transformed percentage, $c t=$ number of plants with crown cankers, $r=2$ (for a binary response), $k=$ a constant which was set equal to $r$, and $n=$ total number of plants (Santner and Duffy 1989). In tables, back-transformed values $>84.0$ and values of E. elaterium correspond to percentages of 100.0 and values $\leq 14.0$ correspond to percentages of 0.0 (no cankers present). Species had a significant effect in all three experiments $(P \leq 0.0002)$. Therefore, linear contrasts were written to compare species. The block factor was excluded from the model because it was not significant in any experiment $(P \geq 0.13)$.

Slopes of the canker progress were calculated for the interval between inoculation and the first postinoculation rating, except for four species in spring 2016, which had low levels of crown cankers before the research plots were inoculated. Therefore, the first rating in spring 2016 was done prior to inoculation and slopes for these species were calculated for the interval between the first and second rating. The slopes of canker progress were analyzed with PROC GLIMMIX. The effects of species, experiment, and their interaction were included as fixed effects and block within years was included as a random effect. The Gaussian distribution was used as the response distribution and the identity was used as the link function. Due to a significant speciesexperiment interaction, the datasets were analyzed separately for each experiment. To adjust for nonnormality and inequality of variances, the data from spring 2016 was square-root transformed before analysis. Using PROC CORR, Pearson correlation coefficients between incidence of crown cankers and incidence of fruiting bodies were calculated for each individual experiment and for data combined from all three experiments.

\section{Results}

Severity of foliar blight. GSB was significantly more severe in fall 2016 than in spring 2015 and $2016(P<0.0001$, from preliminary analysis of combined datasets). Foliar severity was $>70 \%$ on 6 of the 14 species in fall 2016 whereas, in the two previous seasons, severity was $\leq 65 \%$ on all species (Table 2). There were species-experiment interactions for both foliar severity and canker incidence based on AUDPC values and final percentages $(P<0.0001)$. Therefore, all datasets were analyzed separately for each experiment. Symptoms of foliar blight were found on all species in all experiments except on Z. pallidinervia in 2015 (Table 2). Lesions with fruiting bodies of $S$. citrulli were present on thorns of A. horridus (Fig. 1A). 
Three species (E. elaterium, A. sagittifolia, and C. melo) were among the three most susceptible species across all experiments based on AUDPC and final severity, except for C. melo in 2015 (Fig. 1B and C). The AUDPC of $E$. elaterium was consistently among the two highest values and significantly higher than all species, with the exception of A. sagittifolia and C. melo (Table 3 ). The AUDPC of A. sagittifolia was significantly higher than the AUDPC of $C$. melo in 2015 and in fall 2016. In each experiment, $K$. leloja was one of the five most susceptible species and, in 2016, it was at least as susceptible as C. melo. K. leloja, however, had a lower AUDPC than E. elaterium in each experiment. By the end of the season in fall 2016, about half of the plants of C. melo, E. elaterium, and $K$. leloja and almost all plants of $A$. sagittifolia were killed by GSB.

C. grandis and Z. pallidinervia were consistently least affected by S. citrulli. The two species had a significantly lower AUDPC and percent severity based on final ratings than all other species in 2015 and spring 2016. In fall 2016, these two species and S. odorifera had the lowest AUDPC values, although AUDPC of Z. pallidinervia was not significantly different from AUDPC for C. anguria and M. scabra. In spring 2015 and fall 2016, S. odorifera was among the three species with the lowest AUDPC but, in spring 2016, the AUDPC value was only significantly lower than E. elaterium. The AUDPC of $C$. anguria was consistently the fifth lowest and its severity rating was among the four lowest. $C$. grandis and Z. pallidinervia had lower levels of foliar severity than $C$. anguria in all three experiments and, in fall 2016, S. odorifera was also less susceptible than $C$. anguria. The AUDPC for L. sphaerica was less than the AUDPC for C. melo in each experiment.

Based on severity of foliar blight at the end of the experiments, C. grandis and Z. pallidinervia were consistently among the three least susceptible species although, in fall 2016, Z. pallidinervia also grouped with four moderately susceptible species ( $C$. anguria, $C$. ecuadorensis, L. sphaerica, and M. scabra) (Table 2). In general, the data sets for AUDPC and percentages at the end of the experiment are in correspondence. The four species A. sagittifolia, C. melo, E. elaterium, and $K$. leloja were consistently among the species most susceptible to foliar blight, whereas $C$. grandis and $Z$. pallidinervia were consistently highly resistant to the foliar blight phase of GSB in this study.

S. citrulli was successfully recovered from leaves of all included species in at least one experiment. Recovery levels in 2015 were lower than in the 2016 seasons. Overall, there were few differences among species in pathogen recovery. In 2015 , recovery was lowest for A. sagittifolia and M. scabra whereas, in spring 2016, it was lowest for M. scabra and Z. pallidinervia. The pathogen was not recovered from leaves of $C$. grandis, $L$. sphaerica, $S$. odorifera, and $Z$. pallidinervia and thorns of $A$. horridus in 2015 because no symptomatic leaves could be found at the time of sampling.

In fall 2016, symptoms of powdery mildew caused by Podosphaera xanthii were observed on $C$. digitata, $C$. zambianus, and M. scabra (Rennberger et al. 2018). The occurrence of powdery mildew did not affect the results of the experiment because the results were in general agreement with the results of the preceding two experiments.

Incidence of crown cankers. Cankers formed on crowns of most species, except $C$. grandis, S. odorifera, and Z. pallidinervia in 2015 and $C$. grandis in spring 2016 (Table 2). At the end of each experiment, cankers were present on all plants of A. sagittifolia, C. melo, C. digitata, E. elaterium, and $K$. leloja. On A. horridus and C. digitata, cankers developed on all plants in two experiments. The characteristic amber-brown gummy exudate was observed on stems of A. sagittifolia, C. digitata, C. melo, C. zambianus, E. elaterium, $K$. leloja, and L. sphaerica.

In fall 2016, the percentage of crowns with cankers was significantly $(P<0.0001)$ greater than in the previous two experiments and, in 2015 , it was significantly $(P \leq 0.0405)$ less than in the 2016 seasons (Table 2). Despite significant interactions across experiments for most species, species had clear susceptibility patterns to crown cankers. As expected, $C$. melo was among the species most susceptible to crown cankers in all three experiments for both AUDPC and final incidence. The AUDPC of K. leloja was statistically equal to that of $C$. melo in all three experiments (Table 3 ). E. elaterium had an equally high AUDPC as C. melo and $K$. leloja in 2015 and fall 2016. A. sagittifolia and C. zambianus were among the four most susceptible species in fall 2016 and grouped with E. elaterium in all experiments.

C. grandis and $S$. odorifera were the species least susceptible to crown cankers in all experiments. In 2015, these two species plus L. sphaerica and Z. pallidinervia had significantly lower AUDPC values for canker incidence than any other species (Table 3). In spring 2016, AUDPC for $C$. grandis was significantly smaller than for L. sphaerica and, in fall 2016, it was smaller than for Z. pallidinervia and L. sphaerica. AUDPC values did not differ significantly

Table 2. Percentage incidence and severity of gummy stem blight compared within three seasons in 2015 and 2016 for 15 cucurbit species inoculated with Stagonosporopsis citrulli ${ }^{\mathrm{w}}$

\begin{tabular}{|c|c|c|c|c|c|c|}
\hline \multirow[b]{2}{*}{ Species } & \multicolumn{3}{|c|}{ Foliar severity } & \multicolumn{3}{|c|}{ Incidence of crown cankers ${ }^{x}$} \\
\hline & 7 August 2015 & 5 August 2016 & 20 October 2016 & 23 July 2015 & 6 August 2016 & 16 October 2016 \\
\hline Acanthosicyos horridus & $65.1 \mathrm{a}$ & $38.9 \mathrm{~b}$ & 95.2 & $84.8 \mathrm{a}$ & $83.5 \mathrm{ab}$ & 71.4 abcdy \\
\hline Apodanthera sagittifolia & $46.6 \mathrm{bc}$ & $60.4 \mathrm{a}$ & 96.3 & $88.3 \mathrm{a}$ & $84.4 \mathrm{ab}$ & $80.6 \mathrm{abc}$ \\
\hline Coccinia grandis & $0.7 \mathrm{f}$ & $8.6 \mathrm{e}$ & 15.4 & $11.1 \mathrm{~b}$ & $11.8 \mathrm{c}$ & $30.6 \mathrm{~d}$ \\
\hline Cucumis anguria & $10.9 \mathrm{e}$ & $16.6 \mathrm{~d}$ & 31.7 & $73.9 \mathrm{a}$ & $75.0 \mathrm{ab}$ & $83.3 \mathrm{abc}$ \\
\hline Cucumis melo 'Athena' & $42.8 \mathrm{c}$ & $54.2 \mathrm{a}$ & 87.1 & 88.9 a & $88.6 \mathrm{a}$ & $88.6 \mathrm{a}$ \\
\hline Cucumis zambianus & $28.1 \mathrm{~d}$ & $36.1 \mathrm{~b}$ & 47.1 & $66.7 \mathrm{a}$ & $86.1 \mathrm{a}$ & 88.9 a \\
\hline Cucurbita digitata & $44.3 \mathrm{bc}$ & $24.0 \mathrm{~cd}$ & 73.8 & 88.9 a & $59.1 \mathrm{ab}$ & $87.5 \mathrm{ab}$ \\
\hline Cucurbita ecuadorensis & $29.2 \mathrm{~d}$ & $21.7 \mathrm{~cd}$ & 33.3 & $25.0 \mathrm{~b}$ & $77.5 \mathrm{ab}$ & 88.9 a \\
\hline Ecballium elaterium & $54.1 \mathrm{abc}$ & $54.2 \mathrm{a}$ & $87.7 \mathrm{ab}$ & $87.6 \mathrm{a}$ & $77.8 \mathrm{ab}$ & $79.0 \mathrm{abc}$ \\
\hline Gynostemma pentaphyllum ${ }^{\mathrm{z}}$ & 51.7 & 29.2 & n.d. & 23.5 & 20.0 & n.d. \\
\hline Kedrostis leloja & $57.8 \mathrm{ab}$ & $54.4 \mathrm{a}$ & $80.4 \mathrm{bc}$ & 88.9 a & $80.7 \mathrm{ab}$ & $86.8 \mathrm{ab}$ \\
\hline Lagenaria sphaerica & $14.0 \mathrm{e}$ & $29.5 \mathrm{bc}$ & $35.4 \mathrm{e}$ & $14.7 \mathrm{~b}$ & $41.7 \mathrm{~b}$ & $69.4 \mathrm{abc}$ \\
\hline Melothria scabra & $41.5 \mathrm{c}$ & $17.1 \mathrm{~d}$ & $34.6 \mathrm{e}$ & $88.9 \mathrm{a}$ & $76.8 \mathrm{ab}$ & $74.7 \mathrm{abc}$ \\
\hline Sicana odorifera & $14.9 \mathrm{e}$ & $28.6 \mathrm{bc}$ & $20.4 \mathrm{f}$ & $11.1 \mathrm{~b}$ & $39.1 \mathrm{bc}$ & $58.9 \mathrm{c}$ \\
\hline Zehneria pallidinervia & $0.0 \mathrm{f}$ & $3.6 \mathrm{f}$ & $25.4 \mathrm{ef}$ & $13.8 \mathrm{~b}$ & $25.0 \mathrm{c}$ & $62.3 \mathrm{bc}$ \\
\hline
\end{tabular}

${ }^{w}$ Each value is the mean of four replications of the final rating. Means with the same letters within seasons do not differ significantly; Fisher's least significant difference test, $P=0.05 ;$ n.d. $=$ no data due to exclusion of Gynostemma pentaphyllum after the first two seasons.

${ }^{x}$ Percentages of crowns with cankers were back-transformed from categorical data analysis in PROC CATMOD (SAS). Values $>84.0$ and values of E. elaterium correspond to percentages of 100.0 and values $\leq 14.0$ correspond to percentages of 0.0 (no cankers present) because a Bayes estimator was used in the analysis instead of the actual percentages.

y Not significantly different from $C$. grandis due to missing values of A. horridus.

${ }^{\mathrm{z}}$ Excluded from analyses due to large number of plants killed by Pythium spp. 
among L. sphaerica, S. odorifera, and Z. pallidinervia in any experiment. Z. pallidinervia had significantly fewer cankers than $M$. scabra in spring 2015 and 2016 but not in fall 2016.

Overall, there were fewer differences for the percentages of plants with crown cankers on the last rating dates than for AUDPC based on canker incidence. $C$. grandis, $S$. odorifera, and Z. pallidinervia had consistently lower percentages of crowns with cankers compared with $C$. melo and C. zambianus (Table 2). In addition, L. sphaerica had significantly fewer cankers than $C$. melo in 2015 and spring 2016. Although $C$. ecuadorensis was grouped with the three least susceptible species in 2015, in fall 2016, canker incidence was
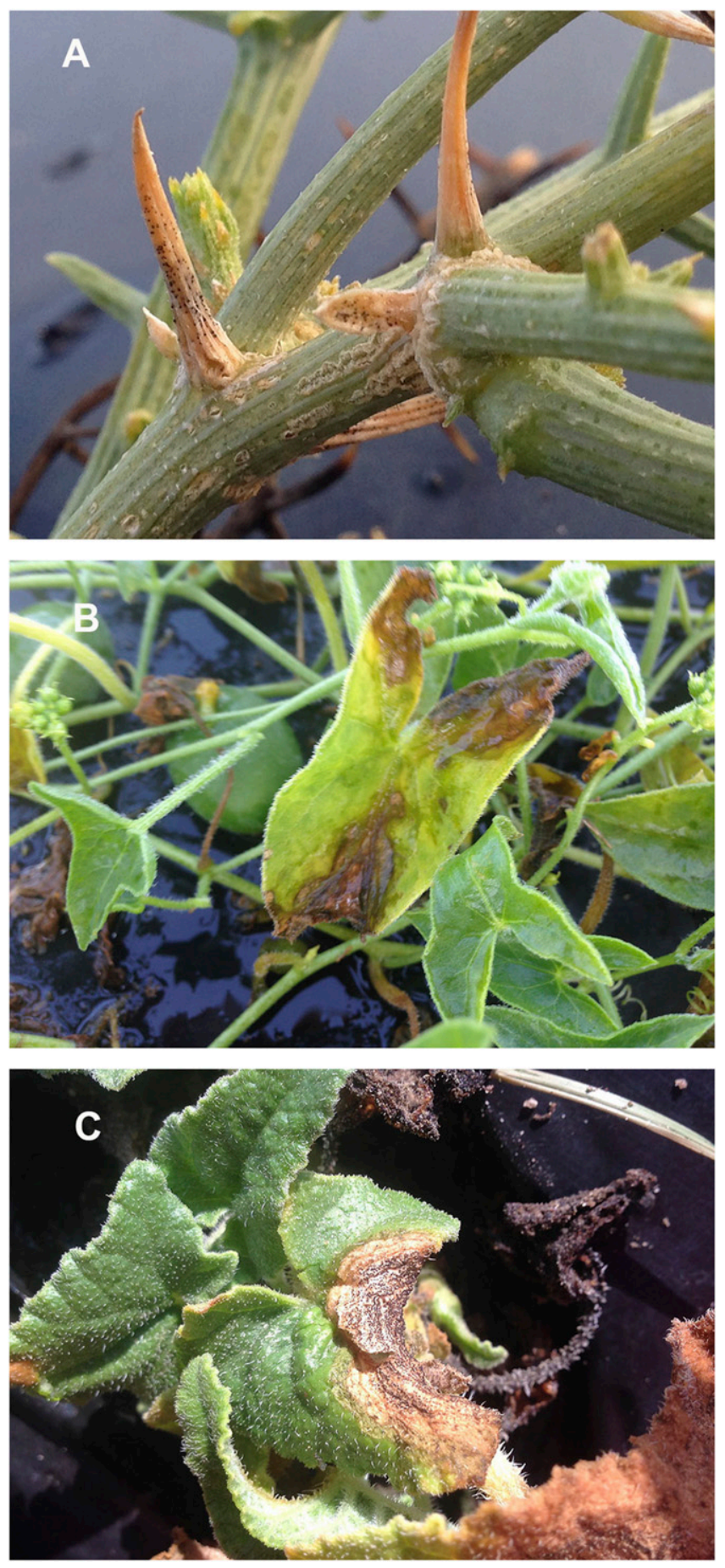

Fig. 1. Typical symptoms of gummy stem blight on leaves of new cucurbit host species. A, Diseased thorns of Acanthosicyos horridus colonized by Stagonosporopsis citrulli; thorn on the left with fruiting bodies of the pathogen. B, Three water-soaked lesions on a leaf of Apodanthera sagittifolia. C, Lesion with abundant sporulation of S. citrulli on a leaf of Ecballium elaterium. greater than on those three species (Table 2). The four species A. sagittifolia, C. melo, C. zambianus, and K. leloja grouped with the species showing the highest incidences of crown cankers in all experiments and were the only species with final incidence values $>80 \%$, except for C. zambianus in 2015. A. horridus, A. sagittifolia, C. anguria, C. melo, E. elaterium, and $K$. leloja had consistently high incidences of cankers that did not differ among experiments (speciesexperiment interaction $P \geq 0.23$, from combined analysis). With few exceptions, the five species A. sagittifolia, C. melo, C. zambianus, E. elaterium, and $K$. leloja were the most susceptible to crown cankers (Fig. 2), and the three species C. grandis, S. odorifera, and
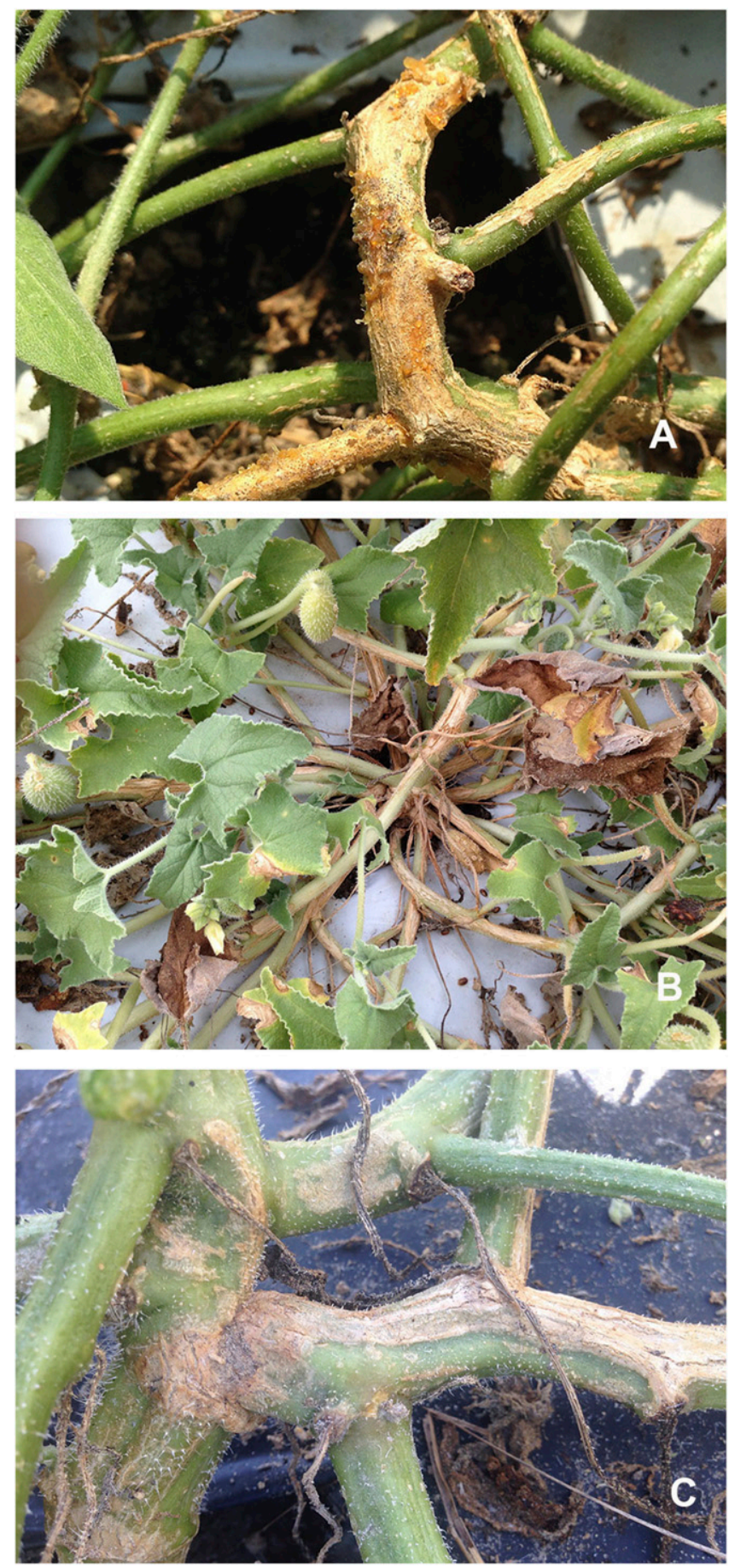

Fig. 2. Typical symptoms of gummy stem blight caused by Stagonosporopsis citrulli on crowns of new cucurbit host species. A, Canker and abundant gummy exudate on crown of Apodanthera sagittifolia. B, Cankers and necrotic lesions on crown and stems of Ecballium elaterium. C, Corky cankers on crown of Cucumis zambianus. 
Z. pallidinervia were the least susceptible, showing only minor symptoms across all three experiments.

S. citrulli was successfully recovered from crowns with cankers of all species in at least one experiment. Recovery was significantly lower in 2015 than in $2016(P<0.0001)$ but there was no difference between the two experiments in $2016(P=0.46)$. The lowest percent recovery was from $C$. grandis, which was significantly less than from all other species except $M$. scabra, which had the second lowest recovery. Otherwise, there were few significant differences in recovery from crowns.

There were several notable differences among species within the genera Cucurbita and Cucumis. Within the genus Cucurbita, final disease severity of $C$. ecuadorensis was lower than that of $C$. digitata in 2015 and fall 2016 (Table 2). Both Cucurbita spp. had higher AUDPC values for crown cankers than the three most resistant species and lower AUDPC values than the three most susceptible species in 2015 and spring 2016. Within the genus Cucumis, foliar severity of C. anguria at the end of the experiments was consistently the lowest of the three species. C. zambianus was consistently more susceptible than $C$. anguria but less susceptible than C. melo (Table 2). C. anguria had a lower AUDPC of crown canker incidence than C. melo in 2015 and spring 2016 but final incidences of crown cankers did not differ in any experiment.

Comparisons among geographic origins and tribes. The four tribes and four geographic origins represented by the cucurbit species included in this study were compared using linear contrasts. AUDPC for foliar disease was significantly less severe for the tribes Benincaseae and Cucurbiteae than for Bryonieae and Coniandreae in all experiments, except that the AUDPC values of Coniandreae and Cucurbiteae were not significantly different in spring 2016. Benincaseae had the lowest AUDPC in all experiments, with the exception that Cucurbiteae was equally low in fall 2016. In all experiments, Cucurbiteae and Benincaseae also were the least susceptible tribes based on AUDPC calculated from crown incidence data (Table 4). In 2015 and spring 2016, Cucurbiteae had a significantly lower crown incidence AUDPC than all other tribes (single-degree-of-freedom contrasts, $P \leq 0.05$ ).

The AUDPC for percent severity among African species was among the statistically lowest AUDPC values in all experiments (Table 5). South American species consistently had the second lowest severity. The European species E. elaterium was the most susceptible species based on geographic origins (Table 5). Severity of North American species was intermediate in 2015 and spring 2016 and low in fall 2016.

E. elaterium, the only species originating from Europe, had the highest AUDPC based on crown canker incidence in all three experiments but, in 2015, North American species were statistically equal and, in fall 2016, South American species had an equally high AUDPC (Table 5). African species consistently had intermediate AUDPC values. South American species had a significantly lower AUDPC value than African, European, and North American species in 2015. In fall 2016, species split into two groups by geographic origins as African and North American species had statistically lower AUDPC of canker incidence than European and South American species (Table 5).

Development of crown cankers. The data for increase in canker incidence between the first and second ratings (approximately 2 weeks) were analyzed separately for each experiment because there was a species-experiment interaction $(P \leq 0.0001)$. The slopes of crown canker incidence in spring 2016 were significantly lower than in 2015 and fall 2016. $(P<0.0001$, from preliminary analyses of combined datasets). On $C$. grandis and $S$. odorifera, there was a

Table 3. Area under the disease progress curve values calculated from incidence and severity of gummy stem blight on 15 cucurbit species inoculated with Stagonosporopsis citrulli compared within three seasons in 2015 and $2016^{\mathrm{y}}$

\begin{tabular}{|c|c|c|c|c|c|c|}
\hline \multirow[b]{2}{*}{ Species } & \multicolumn{3}{|c|}{ Foliar severity } & \multicolumn{3}{|c|}{ Incidence of crown cankers } \\
\hline & 2015 & Spring 2016 & Fall 2016 & 2015 & Spring 2016 & Fall 2016 \\
\hline Acanthosicyos horridus & $1,005 \mathrm{c}$ & $488 \mathrm{~cd}$ & 699 ef & $1,764 \mathrm{e}$ & 3,014 abc & $1,012 \mathrm{ef}$ \\
\hline Apodanthera sagittifolia & $1,492 \mathrm{ab}$ & $716 \mathrm{bc}$ & $1,771 \mathrm{a}$ & $2,646 \mathrm{abc}$ & $1,265 \mathrm{~cd}$ & $2,650 \mathrm{a}$ \\
\hline Coccinia grandis & $12 \mathrm{~g}$ & $148 \mathrm{e}$ & $240 \mathrm{j}$ & $0 \mathrm{~g}$ & $0 \mathrm{f}$ & $659 \mathrm{f}$ \\
\hline Cucumis anguria & $429 \mathrm{~d}$ & $502 \mathrm{~cd}$ & $418 \mathrm{gh}$ & $1,868 \mathrm{de}$ & $1,648 \mathrm{bcd}$ & $2,112 a b c$ \\
\hline Cucumis melo 'Athena' & $979 \mathrm{c}$ & $945 \mathrm{ab}$ & $1,211 \mathrm{bc}$ & $3,066 \mathrm{ab}$ & $5,208 \mathrm{a}$ & $2,555 \mathrm{a}$ \\
\hline Cucumis zambianus & $934 \mathrm{c}$ & $852 \mathrm{bc}$ & $785 \mathrm{de}$ & 2,100 cde & $3,195 \mathrm{ab}$ & $2,650 \mathrm{a}$ \\
\hline Cucurbita digitata & $1,064 \mathrm{c}$ & $816 \mathrm{bc}$ & $920 \mathrm{~d}$ & $2,317 \mathrm{~cd}$ & $761 \mathrm{de}$ & $2,360 a b$ \\
\hline Cucurbita ecuadorensis & $921 \mathrm{c}$ & $624 \mathrm{bcd}$ & $554 \mathrm{fg}$ & $348 \mathrm{f}$ & $1,696 \mathrm{bcd}$ & $2,511 \mathrm{a}$ \\
\hline Ecballium elaterium & $1,796 \mathrm{a}$ & $1,593 \mathrm{a}$ & $1,234 \mathrm{~b}$ & $2,596 \mathrm{bc}$ & $3,138 \mathrm{ab}$ & $2,650 \mathrm{a}$ \\
\hline Gynostemma pentaphyllum $^{2}$ & 1,715 & 510 & n.d. & 530 & 47 & n.d. \\
\hline Kedrostis leloja & $1,385 \mathrm{~b}$ & $761 \mathrm{bc}$ & $987 \mathrm{~cd}$ & $3,253 \mathrm{a}$ & $2,361 \mathrm{bc}$ & $2,337 \mathrm{ab}$ \\
\hline Lagenaria sphaerica & $227 \mathrm{e}$ & $527 \mathrm{~cd}$ & $533 \mathrm{fg}$ & $18 \mathrm{~g}$ & $440 \mathrm{de}$ & $1,709 \mathrm{bcd}$ \\
\hline Melothria scabra & $823 \mathrm{c}$ & $352 \mathrm{~d}$ & $372 \mathrm{hi}$ & $2,412 \mathrm{c}$ & $1,154 \mathrm{~cd}$ & 1,023 ef \\
\hline Sicana odorifera & $106 \mathrm{f}$ & $558 \mathrm{bcd}$ & $278 \mathrm{ij}$ & $0 \mathrm{~g}$ & 123 ef & $1,191 \mathrm{def}$ \\
\hline Zehneria pallidinervia & $0 \mathrm{~g}$ & $64 \mathrm{f}$ & $352 \mathrm{hij}$ & $0 \mathrm{~g}$ & 94 ef & $1,627 \mathrm{cde}$ \\
\hline
\end{tabular}

${ }^{\mathrm{y}}$ Each value is the mean of four replications. Means with the same letters within experiments are not significantly different; Fisher's least significant difference test, $P=0.05$; n.d. = no data due to exclusion of Gynostemma pentaphyllum after the first two experiments.

${ }^{\mathrm{z}}$ Excluded from analyses due to large number of plants killed by Pythium spp.

Table 4. Contrasts among cucurbit tribes for area under the disease progress curve calculated from incidence of crown cankers and severity of foliar blight ${ }^{\mathrm{w}}$

\begin{tabular}{|c|c|c|c|c|c|c|c|c|c|c|c|c|}
\hline \multirow[b]{2}{*}{ Tribe $(N)^{z}$} & \multicolumn{6}{|c|}{ Incidence of crown cankers ${ }^{x}$} & \multicolumn{6}{|c|}{ Severity of foliar blight ${ }^{y}$} \\
\hline & 2015 & SE & Spring 2016 & $\mathbf{S E}$ & Fall 2016 & SE & 2015 & SE & Spring 2016 & $\mathbf{S E}$ & Fall 2016 & SE \\
\hline Benincaseae (8) & $987 \mathrm{~b}$ & 425 & $1,326 \mathrm{~b}$ & 647 & $1,669 \mathrm{~b}$ & 261 & $413 \mathrm{~d}$ & 154 & $369 \mathrm{c}$ & 108 & $543 \mathrm{~b}$ & 111 \\
\hline Bryonieae (1) & $2,596 \mathrm{a}$ & 0 & $3,138 \mathrm{a}$ & 0 & $2,650 \mathrm{a}$ & 0 & $1,796 \mathrm{a}$ & 0 & $1,593 \mathrm{a}$ & 0 & $1,235 \mathrm{a}$ & 0 \\
\hline Coniandreae (2) & $2,942 \mathrm{a}$ & 304 & $1,773 \mathrm{ab}$ & 548 & $2,493 \mathrm{a}$ & 157 & $1,438 \mathrm{~b}$ & 54 & $738 \mathrm{~b}$ & 23 & $1,350 \mathrm{a}$ & 392 \\
\hline Cucurbiteae (3) & $496 \mathrm{c}$ & 14 & $710 \mathrm{c}$ & 457 & $2021 \mathrm{ab}$ & 417 & $596 \mathrm{c}$ & 298 & $657 \mathrm{~b}$ & 77 & $553 \mathrm{~b}$ & 186 \\
\hline
\end{tabular}

${ }^{\mathrm{w}}$ Each value is the mean of four replications. Means with the same letters within seasons do not differ significantly; single-degree-of-freedom contrasts, $P=0.05$.

$\mathrm{SE}=$ standard error, calculated from back-transformed values of individual species.

x Number of ratings in 2015, spring 2016, and fall 2016 were three, four, and two, respectively.

y Number of ratings in 2015, spring 2016, and fall 2016 were seven, nine, and five, respectively.

${ }^{\mathrm{z}} \mathrm{N}=$ number of species. 
consistent lack of canker development at the beginning of the disease progress curve between the first and second ratings $(P \geq 0.11)$. C. grandis had no cankers throughout the experiments in 2015 and spring 2016 but cankers were observed starting 24 days after inoculation (dai) in fall 2016. No cankers developed on S. odorifera over the course of the experiment in 2015 but appeared 37 dai in spring 2016 and 24 dai in fall 2016. Despite the earlier onset of canker development in fall 2016, these two species still had the fewest cankers at the end of the experiment. In all three experiments, $C$. melo and $K$. leloja had the fastest increase of canker incidence per day (Table 6). E. elaterium grouped with the species with the highest rates of increase in 2016. Two additional species (A. sagittifolia and C. zambianus) grouped with the five species that had the highest rate of canker increase in 2015 and fall 2016 (Table 6).

Incidence of fruiting bodies on crown cankers. The percentage of crowns with fruiting bodies of $S$. citrulli in fall 2016 was significantly higher $(P \leq 0.0011)$ than in 2015 and spring 2016. No fruiting bodies were found on C. ecuadorensis, L. sphaerica, G. pentaphyllum, and Z. pallidinervia in 2015; C. grandis and S. odorifera in 2015 and spring 2016; or M. scabra in fall 2016. The data for incidence of fruiting bodies on crown cankers were analyzed separately for each experiment because there was an overall species-experiment interaction $(P \leq 0.0001)$. The species-experiment interaction was significant for A. sagittifolia, C. anguria, C. digitata, C. ecuadorensis, C. zambianus, and E. elaterium $(P \leq 0.0096)$ but not for the remaining eight species $(P \geq 0.0547)$. The main reasons for the interaction were the absence of fruiting bodies on crowns of C. ecuadorensis in 2015 and low incidence of fruiting bodies on A. sagittifolia in spring 2016.

Among all 15 species, C. melo consistently had the highest incidence of fruiting bodies. Fruiting bodies were present on $\geq 92 \%$ of its crowns in every experiment (Table 7). Several other species had similar levels of fruiting body incidence. A. sagittifolia, E. elaterium, and $K$. leloja consistently grouped with the five species with the highest incidence of fruiting bodies, except for A. sagittifolia in spring 2016 and $K$. leloja in fall 2016. Five species-C. grandis, L. sphaerica, M. scabra, S. odorifera, and Z. pallidinervia - consistently were among the species with the lowest incidence of fruiting bodies on crowns. C. anguria also had fewer fruiting bodies than C. melo in all experiments.

There was a significant $(P<0.0001)$ correlation (Pearson's $r)$ between the incidence of crown cankers and the incidence of fruiting bodies on cankers in all experiments. The correlation was moderate to high: Pearson's $r=0.7062,0.6262$, and 0.5550 in 2015, spring 2016 , and fall 2016, respectively. There also was a significant $(P<$ $0.0001)$ moderately high correlation between the two variables across experiments (Pearson's $r=0.6373$ ).

\section{Discussion}

To the best of our knowledge, this field study is the first confirmation of susceptibility to both phases of GSB, foliar blight and crown cankers, caused by $S$. citrulli on 14 new cucurbit species. Thus, the host range of $S$. citrulli is wider than previously reported (Keinath 2011). Susceptibility to GSB had been reported on 24 species in 13 genera of cucurbits (Jiang et al. 2015; Keinath 2011). This study expands the known list of affected plants to 37 species in 22 genera (Table 6). Because $S$. citrulli infected all 14 species tested, its host range might be much wider than what is known currently. Immunity against GSB appears to be extremely rare or even absent in the family Cucurbitaceae. The 14 new host species reported in this study represent 12 genera and four taxonomic tribes.

The family Cucurbitaceae comprises 15 tribes, of which 8 are now known to include species susceptible to GSB. This study included species in three of the six tribes with species known previously to be susceptible to GSB: Benincaseae, Bryonieae, and Cucurbiteae. No members of the tribes Momordiceae, Sicyoceae, and Siratieae were included; in part, because existing documentation of their susceptibility was considered to be sufficient (Keinath 2011; Schaefer and Renner 2011). Susceptibility was confirmed for two new tribes, Coniandreae and Gomphogyneae, from which susceptibility had not been reported previously. The two species from Coniandreae, $A$. sagittifolia and $K$. leloja, were highly susceptible to both phases of the disease (foliar blight and crown cankers). G. pentaphyllum, a cucurbit native to moist forests in Asia and member of the tribe Gomphogyneae (Schaefer and Renner 2011), was initially included in this study but had to be excluded because of poor germination, lack of plant vigor due to the hot climate and wet soil, and the number of transplants that were killed by Pythium spp. Nonetheless, the species was successfully inoculated and the pathogen was recovered from crowns and leaves in two experiments.

Muskmelon was very susceptible to GSB in this study, as reported previously (Chiu and Walker 1949; Crinò et al. 2007; Keinath 2008, 2014a). Although 8 other species had incidences of crown cankers that did not differ from muskmelon in all three experiments, muskmelon was the most susceptible species of the 15 species included in this study because incidence was $100 \%$ in each experiment. These findings confirm earlier studies where similar differences in susceptibility were observed among various cucurbit hosts. Chiu and Walker (1949) reported formation of cankers on bottle gourd, cucumber, muskmelon, and five species of Cucurbita, with muskmelon being most susceptible. In the study by dos Santos et al. (2009), Cucumis was among the most susceptible genera, while Luffa and Cucurbita were the least susceptible. The fact that there were fewer significant differences in susceptibility to crown cankers in the percentage data compared with the AUDPC was caused by differences among the cucurbit species in the onset of crown cankers and the speed at which they developed and spread (Table 6). Fry (1978) also compared AUDPC and final disease ratings and found that AUDPC generally was a better measure to evaluate late blight resistance of potato cultivars.

In contrast to the experiments done by Grossenbacher (1909), in which $C$. anguria was highly resistant to stem cankers, this species was susceptible to crown cankers in our study. The pathogen colonized crowns and was successfully isolated in all three experiments. Grossenbacher inoculated $C$. anguria 10 times but did not observe any symptoms. A possible explanation for the failure of infection throughout Grossenbacher's experiments is that he used mycelium from cultures that were grown on PDA to inoculate through stem wounds. He reported bacterial contamination of the cultures, which might have prevented successful infection by Stagonosporopsis spp.

Table 5. Contrasts among geographic origins of cucurbits for area under the disease progress curve calculated from incidence of crown cankers and severity of foliar blight ${ }^{\mathrm{w}}$

\begin{tabular}{|c|c|c|c|c|c|c|c|c|c|c|c|c|}
\hline \multirow[b]{2}{*}{ Continent $(N)^{\mathrm{z}}$} & \multicolumn{6}{|c|}{ Incidence of crown cankers ${ }^{x}$} & \multicolumn{6}{|c|}{ Severity of foliar blight ${ }^{y}$} \\
\hline & 2015 & SE & Spring 2016 & SE & Fall 2016 & SE & 2015 & SE & Spring 2016 & SE & Fall 2016 & SE \\
\hline Africa (8) & $1,051 \mathrm{~b}$ & 470 & $1,463 \mathrm{~b}$ & 642 & $1,833 \mathrm{~b}$ & 207 & $458 \mathrm{~d}$ & 184 & $407 \mathrm{c}$ & 111 & $615 \mathrm{c}$ & 117 \\
\hline Europe (1) & $2,596 \mathrm{a}$ & 0 & $3,138 \mathrm{a}$ & 0 & $2,650 \mathrm{a}$ & 0 & $1,796 \mathrm{a}$ & 0 & $1,593 \mathrm{a}$ & 0 & $1,235 \mathrm{a}$ & 0 \\
\hline North America (2) & $2,364 \mathrm{a}$ & 1 & $947 \mathrm{~b}$ & 197 & $1,691 \mathrm{~b}$ & 668 & $871 \mathrm{~b}$ & 121 & $536 \mathrm{bc}$ & 232 & $616 \mathrm{c}$ & 274 \\
\hline South America (3) & $546 \mathrm{c}$ & 15 & $859 \mathrm{~b}$ & 469 & $2,117 \mathrm{a}$ & 465 & $698 \mathrm{c}$ & 402 & $629 \mathrm{~b}$ & 46 & $753 \mathrm{~b}$ & 459 \\
\hline
\end{tabular}

${ }^{\mathrm{w}}$ Each value is the mean of four replications. Means with the same letters within seasons do not differ significantly; single-degree-of-freedom contrasts, $P=0.05$.

$\mathrm{SE}=$ standard error, calculated from back-transformed values of individual species.

${ }^{x}$ Number of ratings in 2015, spring 2016, and fall 2016 were three, four, and two, respectively.

y Number of ratings in 2015, spring 2016, and fall 2016 were seven, nine, and five, respectively.

${ }^{\mathrm{z}}$ Geographic origin. $N=$ number of species. 
despite the wounding. It is also possible that Grossenbacher used isolates of $S$. cucurbitacearum, which have been identified from New York (Somai et al. 2002, Stewart et al. 2015). Isolates of S. cucurbitacearum might have a host preference for Cucurbita spp. because $S$. cucurbitacearum was recovered most frequently from this genus. However, Stewart et al. (2015) did not find a host specialization in experiments with $C$. moschata.

The two isolates of $S$. citrulli used for inoculation in this study were both originally recovered from watermelon, a genus that was not included in this study. The fact that these isolates successfully caused disease on all tested species shows the small or nonexistent effect of host origin on pathogenicity of $S$. citrulli, which confirms previous observations that isolate virulence is not correlated with

Table 6. Daily increase of incidence of crown cankers caused by Stagonosporopsis citrulli compared within experiments for 15 cucurbit species ${ }^{\mathrm{X}}$

\begin{tabular}{|c|c|c|c|}
\hline Species & 2015 & Spring 2016 & Fall 2016 \\
\hline Acanthosicyos horridus & $0.0 \mathrm{e}$ & $0.8 \mathrm{ab}^{\mathrm{y}}$ & $2.5 \mathrm{bcd}$ \\
\hline Apodanthera sagittifolia & $5.0 \mathrm{bc}$ & $0.1 \mathrm{~b}$ & $4.2 \mathrm{a}$ \\
\hline Coccinia grandis & $0.0 \mathrm{e}$ & $0.0 \mathrm{~b}$ & $0.9 \mathrm{e}$ \\
\hline Cucumis anguria & $0.0 \mathrm{e}$ & $0.0 \mathrm{~b}^{\mathrm{y}}$ & $3.1 \mathrm{abc}$ \\
\hline Cucumis melo 'Athena' & $8.2 \mathrm{a}$ & $3.4 \mathrm{a}^{\mathrm{y}}$ & $4.0 \mathrm{a}$ \\
\hline Cucumis zambianus & $5.7 \mathrm{~b}$ & $0.1 \mathrm{~b}^{\mathrm{y}}$ & $4.2 \mathrm{a}$ \\
\hline Cucurbita digitata & $2.5 \mathrm{~d}$ & $0.1 \mathrm{~b}$ & $3.6 \mathrm{ab}$ \\
\hline Cucurbita ecuadorensis & $0.0 \mathrm{e}$ & $0.8 \mathrm{ab}$ & $3.9 \mathrm{a}$ \\
\hline Ecballium elaterium & $4.6 \mathrm{bc}$ & $1.7 \mathrm{a}$ & $4.2 \mathrm{a}$ \\
\hline Gynostemma pentaphyllum ${ }^{\mathrm{z}}$ & 0.0 & 0.0 & n.d. \\
\hline Kedrostis leloja & $9.6 \mathrm{a}$ & $2.0 \mathrm{a}$ & $3.5 \mathrm{abc}$ \\
\hline Lagenaria sphaerica & $0.0 \mathrm{e}$ & $0.1 \mathrm{~b}$ & $2.5 \mathrm{bcd}$ \\
\hline Melothria scabra & $3.2 \mathrm{~cd}$ & $0.1 \mathrm{~b}$ & $0.9 \mathrm{e}$ \\
\hline Sicana odorifera & $0.0 \mathrm{e}^{-1}$ & $0.0 \mathrm{~b}$ & $1.6 \mathrm{de}$ \\
\hline Zehneria pallidinervia & $0.0 \mathrm{e}$ & $0.0 \mathrm{~b}$ & $2.5 \mathrm{~cd}$ \\
\hline
\end{tabular}

${ }^{x}$ Each value is the mean of four replications of the final rating. Means with the same letters within experiments do not differ significantly; Fisher's least significant difference test, $P=0.05$; n.d. $=$ no data due to exclusion of Gynostemma pentaphyllum after the first two experiments. Rates were calculated for the interval between inoculation and the first rating.

y Slopes for species with cankers before inoculation were calculated between the first two ratings.

${ }^{\mathrm{z}}$ Excluded from analyses due to large number of plants killed by Pythium spp.

Table 7. Incidence of fruiting bodies of Stagonosporopsis citrulli compared within three experiments in 2015 and 2016 for 15 cucurbit species ${ }^{\mathrm{x}}$

\begin{tabular}{lccc}
\hline Species & $\begin{array}{c}\text { 23 July } \\
\mathbf{2 0 1 5}\end{array}$ & $\begin{array}{c}\text { 6 August } \\
\mathbf{2 0 1 6}\end{array}$ & $\begin{array}{c}\text { 16 October } \\
\mathbf{2 0 1 6}\end{array}$ \\
\hline Acanthosicyos horridus & $90.4 \mathrm{a}$ & $54.5 \mathrm{bc}$ & $17.2 \mathrm{de}^{\mathrm{y}}$ \\
Apodanthera sagittifolia & $95.5 \mathrm{a}$ & $10.4 \mathrm{de}$ & $83.3 \mathrm{ab}$ \\
Coccinia grandis & $0.0 \mathrm{c}$ & $0.0 \mathrm{e}$ & $3.5 \mathrm{e}$ \\
Cucumis anguria & $5.7 \mathrm{bc}$ & $17.8 \mathrm{de}$ & $53.8 \mathrm{bc}$ \\
Cucumis melo 'Athena' & $93.3 \mathrm{a}$ & $92.3 \mathrm{a}$ & $96.5 \mathrm{a}$ \\
Cucumis zambianus & $23.6 \mathrm{~b}$ & $60.8 \mathrm{bc}$ & $82.3 \mathrm{ab}$ \\
Cucurbita digitata & $27.0 \mathrm{~b}$ & $13.5 \mathrm{de}$ & $78.3 \mathrm{ab}$ \\
Cucurbita ecuadorensis & $0.0 \mathrm{c}$ & $38.3 \mathrm{~cd}$ & $67.8 \mathrm{ab}$ \\
Ecballium elaterium & $96.2 \mathrm{a}$ & $43.8 \mathrm{c}$ & $85.5 \mathrm{ab}$ \\
Gynostemma & $0.0 \mathrm{c}$ & $2.4 \mathrm{e}$ & $\mathrm{n} . \mathrm{d}$. \\
pentaphyllum & & & \\
Kedrostis leloja & $89.1 \mathrm{a}$ & $74.3 \mathrm{ab}$ & $58.3 \mathrm{bc}$ \\
Lagenaria sphaerica & $0.0 \mathrm{c}$ & $7.3 \mathrm{e}$ & $24.8 \mathrm{cde}$ \\
Melothria scabra & $14.4 \mathrm{bc}$ & $4.3 \mathrm{e}$ & $0.0 \mathrm{e}$ \\
Sicana odorifera & $0.0 \mathrm{c}$ & $0.0 \mathrm{e}$ & $23.3 \mathrm{de}$ \\
Zehneria pallidinervia & $0.0 \mathrm{c}$ & $3.5 \mathrm{e}$ & $30.0 \mathrm{cde}$ \\
\hline
\end{tabular}

${ }^{\mathrm{x}}$ Ratings include both pycnidia and pseudothecia. Each value is the mean of four replications of the final rating. Means with the same letters within experiments do not differ significantly; Fisher's least significant difference test, $P=0.05 ;$ n.d. $=$ no data due to exclusion of Gynostemma pentaphyllum after the first two experiments.

${ }^{y}$ Not significantly different from $C$. grandis due to missing values of A. horridus.

${ }^{\mathrm{z}}$ Excluded from analyses due to large number of plants killed by Pythium spp. host origin (Wiant 1945; Zúniga 1999). It is possible, however, that there were slight effects on pathogen virulence on the different included cucurbits, as was reported in other studies (Chiu and Walker 1949; dos Santos et al. 2009; Keinath 2014a).

In general, all species except $C$. anguria, M. scabra, and G. pentaphyllum were equally susceptible or resistant to foliar blight and crown cankers. C. anguria and $M$. scabra were moderately resistant to foliar blight but clearly susceptible to crown cankers. The reverse appears to be true for G. pentaphyllum, which was resistant to crown cankers but susceptible to foliar blight. Due to problems with severe Pythium root rot on this species, this observation, however, could not be verified statistically. In a previous study, watermelon was found to be less susceptible to crown cankers than to the foliar blight phase of GSB. This was attributed to the potential existence of genes that confer partial resistance to crown cankers (Keinath 2014a). The finding that two species in this study had a resistance pattern the reverse of watermelon infers that there also might be genes encoding for specific resistance to foliar blight.

Differences in susceptibility were observed among the tribes and geographic origins included in this study. The tribe Bryonieae and the European origin grouping each included only one species, the very susceptible E. elaterium; therefore, the results for the comparisons among taxonomic tribes and geographic origins are similar (Tables 4 and 5) even though the single species was compared with different taxonomic and geographical groupings. The foliar blight phase on E. elaterium, A. sagittifolia, and K. leloja, which reached $100 \%$ severity in fall 2016, was as severe as on C. melo. These four most susceptible species represent three taxonomic tribes (Benincaseae, Bryonieae, and Coniandreae). Nevertheless, Benincaseae was consistently the least susceptible tribe, and three of the four most resistant speciesC. grandis, L. sphaerica, and Z. pallidinervia - are members of this tribe. Because seven of the eight species in Benincaseae were from Africa, this convergence explains why African species were the most resistant geographic grouping. In contrast to this, muskmelon also belongs to this tribe. Likewise, the three species from South America were susceptible (A. sagittifolia), intermediately resistant (C. ecuadorensis), and resistant (S. odorifera). In addition, the differences between pairs of species in Cucumis and Cucurbita included in our study, of which one species in both genera was very susceptible and the other moderately resistant to resistant, show the great variability of GSB resistance within genera. Thus, membership in a genus, taxonomic tribe, or geographic origin has no bearing on the resistance level of a given cucurbit species. Similarly, Keinath (2014b) found variations of fungal reproduction on different hosts within the genera Citrullus, Cucumis, and Cucurbita and concluded that generalizations about differential susceptibility of cucurbits to GSB should be restricted to differences among species or horticultural types.

$S$. citrulli attacked and sporulated on thorns of A. horridus. This constitutes the first time that lesions and fruiting bodies were found on this type of plant part. This observation confirms that the pathogen attacks all aboveground vegetative and reproductive plant parts of cucurbits (Chester 1891; Keinath 2011, 2013).

Conditions more conducive to disease development in fall 2016 resulted in higher levels of foliar severity, canker incidence, and sporulation on cankers, despite the fact that the inoculum density was lowest in that experiment. On watermelon, GSB epidemics were reported to begin sooner in fall seasons, which led to higher final levels of disease (Keinath 2000). In fall 2016, dew in the early morning hours and more frequent misting prolonged leaf wetness, which favored disease progress. The lower levels of foliar severity at the end of the spring 2015 experiment compared with spring 2016 likely were due to the shorter season in 2015. The ratings in 2016 that correspond to the time period from inoculation to the final rating in 2015 were lower than or comparable with the 2015 ratings. In addition, in spring 2016, the overall speed at which canker incidence increased was significantly lower than in the other two experiments, although the highest inoculum density was applied in that experiment. This can be attributed to the drier conditions with higher temperatures in spring 2016 (data not shown). The seasonal variations in susceptibility to GSB observed in this study confirm previous reports of 
substantial variations in susceptibility caused by environmental conditions (Lou et al. 2013; St. Amand and Wehner 2001; Wolukau et al. 2007; Zhang et al. 2017).

Both types of fruiting body, which are readily produced by the homothallic fungus $S$. citrulli, were found on crowns of all cucurbits. We did not quantify the ratio of the two types but, in an earlier study, Keinath (2014b) found that pseudothecia were the predominant type of fruiting body. Species that were most susceptible to crown cankers also had the highest incidence of fruiting bodies and the fastest rates of canker development. This pattern was especially consistent for C. melo and K. leloja. Conversely, the most resistant species-C. grandis, S. odorifera, and Z. pallidinervia - consistently had the lowest incidence of fruiting bodies and the slowest rates of increase for cankers. Keinath (2014a) reported that cucurbit cultivars with higher levels of severity or incidence of foliar GSB also had more leaves with fruiting bodies; however, he did not compare disease progress rates among the included cultivars. These observations were confirmed in this study. The rate of sporulation of a pathogen may be regarded as a general indicator of susceptibility. Thomas and Jourdain (1992) and Thomas et al. (2017) evaluated the virulence of Pseudoperonospora cubensis, an oomycete causing downy mildew of cucurbits, based on the level of sporulation on different hosts. Hosts that facilitated lower rates of sporulation were considered less susceptible owing to their interaction with virulence factors involved in pathogen sporulation. Analogously, cucurbit species that consistently had lower incidences of fruiting bodies of $S$. citrulli in this study might impair sporulation by the pathogen through interacting with virulence factors specific to the formation of fruiting bodies.

The cucurbit species included in this study can serve as inoculum sources for S. citrulli in regions where they occur. Schenck (1968) reported that fruiting bodies on crowns of watermelon produced inoculum, particularly ascospores, that contributed significantly to the secondary spread of GSB. In North America, the native $C$. digitata and M. scabra and the introduced E. elaterium could be reservoirs of initial inoculum due to their high levels of susceptibility.

C. anguria had significantly less severe foliar blight than the other two Cucumis spp. in each experiment. However, in contrast to the experiments done by Wehner and St. Amand (1993), in which C. anguria was highly resistant to the foliar blight phase of GSB, this species was only moderately resistant to foliar blight in our study. The pathogen colonized leaves and was successfully isolated in all three experiments. Wehner and St. Amand did not use prepared inoculum solution immediately and did not provide additional nutrients in the spore solution, as recommended by Svedelius (1990); therefore, GSB development may have been restricted in their study. Although C. anguria and C. zambianus are closely related and even cross compatible, the difference in susceptibility between them was substantial. In 2015 and spring 2016, the AUDPC of C. zambianus was as high as that of $C$. melo, a species to which it is only distantly related (Widrlechner et al. 2008). It is unlikely that $C$. anguria could serve as a source of resistance to foliar blight, due to lack of crossability with other Cucumis spp. (Robinson and Decker-Walters 1997).

Resistance to GSB in cucurbits has been studied mainly in cucumber and melon. Although previous research identified different single dominant genes conferring resistance to GSB in various plant introductions (Frantz and Jahn 2004; Norton 1979; Prasad and Norton 1967; Wako et al. 2002; Wolukau et al. 2007; Zúniga et al. 1999), recent studies found resistance to be quantitative and controlled by two quantitative trait loci (QTL) or three pairs of additive epistatic major genes (Lou et al. 2013; Zhang et al. 2017). The variability of GSB resistance and susceptibility in this study reflects the wide range of results found in previous work on GSB resistance and the underlying inheritance. Collectively evaluated, it seems most likely that resistance to this disease of cucurbits is controlled by multiple genes, each contributing to the overall level of resistance.

The two most resistant species found in this study were $C$. grandis and $Z$. pallidinervia. Because of their consistently high levels of resistance to $S$. citrulli, these species could be utilized to identify new QTL associated with GSB resistance of cucurbits. Lou et al. (2013) used introgression lines from a cross between Cucumis hystrix and C. sativus to identify two QTL contributing to GSB foliar resistance. It would be interesting to test several different species of Coccinia and Zehneria for their susceptibility to GSB to identify the genetic background of resistance in these genera. Because the genus Coccinia comprises 27 species adapted to numerous different habitats (Holstein and Renner 2011), a species with significantly higher susceptibility to GSB than C. grandis is likely to exist. A more susceptible Coccinia sp. could be used in a cross with $C$. grandis to map QTL responsible for GSB resistance, similar to Lou et al. (2013). The genus Zehneria, which comprises approximately 65 species from different habitats in Africa, Asia, and Oceania, could be utilized in a similar way (Renner and Pandey 2013, Schaefer and Renner 2011). Before utilization of the

Table 8. Updated list of cucurbit genera known to be susceptible to gummy stem blight caused by Stagonosporopsis spp.

\begin{tabular}{|c|c|c|c|}
\hline Genus $(N)^{\mathbf{y}}$ & Common name & Tribe $^{\mathrm{z}}$ & Reference \\
\hline$\overline{\text { Acanthosicyos (1) }}$ & Nara melon & Benincaseae & This study \\
\hline Apodanthera (1) & Argentinian melon & Coniandreae & This study \\
\hline Benincasa (1) & Wax gourd & Benincaseae & Wiant 1945 \\
\hline Bryonia (3) & Bryony & Bryonieae & Gonnermann and Rabenhorst 1869 \\
\hline Citrullus (2) & Watermelon & Benincaseae & Chester 1891 \\
\hline Coccinia (1) & Ivy gourd & Benincaseae & This study \\
\hline Cucumis (5) & Cucumber, melon & Benincaseae & Saccardo 1891 \\
\hline Cucurbita (7) & Squash, pumpkin & Cucurbiteae & Grossenbacher 1909 \\
\hline Cyclanthera (1) & Wild cucumber & Sicyoeae & Mendes et al. 1998 \\
\hline Ecballium (1) & Squirting cucumber & Bryonieae & This study \\
\hline Gynostemma (1) & Jiaogulan & Gomphogyneae & This study \\
\hline Kedrostis (1) & None & Coniandreae & This study \\
\hline Lagenaria (2) & Bottle gourd & Benincaseae & Grossenbacher 1909 \\
\hline Luffa (2) & Loofah & Sicyoeae & Grossenbacher 1909 \\
\hline Melothria (1) & Mouse melon & Benincaseae & This study \\
\hline Momordica (2) & Bitter melon & Momordiceae & Wiant 1945 \\
\hline Sechium (1) & Chayote & Sicyoeae & Wiant 1945 \\
\hline Sicana (1) & Cassabanana & Cucurbiteae & This study \\
\hline Sicyos (1) & Bur-cucumber & Sicyoeae & Greene 1953 \\
\hline Siraitia (1) & Luohanguo & Siraitieae & Jiang et al. 2015 \\
\hline Trichosanthes (1) & Snake gourd & Sicyoeae & Punithalingam and Holliday 1972 \\
\hline Zehneria (1) & Batwing vine & Benincaseae & This study \\
\hline
\end{tabular}

${ }^{\mathrm{y}} N=$ number of species.

${ }^{\mathrm{z}}$ Classification based on Schaefer and Renner (2011). 
resistance genes of $C$. grandis or Z. pallidinervia, which are the most promising candidates for use in advanced cucurbit breeding, it would be necessary to test them in different environments and with different isolates of the three species of Stagonosporopsis causing GSB on cucurbits. It has been shown that germplasm found to be highly resistant to GSB in one particular environment has to be retested under different conditions for successful use in breeding programs (Wolukau et al. 2007).

A potential use of $C$. grandis and $S$. odorifera, which are resistant to both the canker and foliar blight phases of GSB, might be as rootstocks for grafting cucurbit crops. Grafting is used in cucurbit production to manage Southern root-knot nematode (Meloidogyne incognita) and Fusarium wilt caused by Fusarium oxysporum f. sp. niveum in watermelon, vine decline of melon caused by Monosporascus cannonballus, and other diseases (Cohen et al. 2012; Keinath and Hassell 2014a,b; King et al. 2008; Thies et al. 2015). The cucurbits mainly utilized as rootstocks are bottlegourd (L. siceraria) and interspecific hybrid squash (C. maxima $\times$ C. moschata) (King et al. 2008; Lee 1994). However, all commonly used rootstocks are as susceptible to GSB as seedless watermelon, and the conditions needed for the healing of the graft union are very conducive to disease development (Keinath 2013). Crinò et al. (2007) tested eight interspecific hybrid squash rootstocks to manage GSB on melon and found four rootstocks with high resistance. The development of rootstocks from $C$. grandis and $S$. odorifera could supply growers with a rootstock that is resistant to this important cucurbit disease. Grafting commercial cucurbits on rootstocks of these two species should be possible, because grafts are generally successful with other rootstocks that are members of the tribe Benincaseae, to which most commercially important cucurbits belong (e.g., cucumber, melon, and watermelon). Moreover, grafting watermelon on members of the tribe Cucurbiteae, to which pumpkin, squash, and S. odorifera belong, is now common practice in many production regions (King et al. 2008; Lee 1994). Although $C$. grandis is, as a member of the same taxonomic tribe, more closely related to watermelon and muskmelon, $S$. odorifera might be more suitable as a GSB-resistant rootstock because of its similar stem morphology. The hypocotyl of $C$. grandis thickens at an early developmental stage and expands to a diameter of about $3 \mathrm{~cm}$ to form a caudiciform stem, which is a swollen perennial storage stem at or above ground level (Simpson 2010). This stem morphology could lead to problems in grafting success and compatibility.

In summary, 2 of 14 new species tested, $C$. grandis and Z. pallidinervia, were consistently highly resistant to the foliar blight phase of GSB in this study, whereas A. sagittifolia, C. melo, E. elaterium, and $K$. leloja were among the most susceptible species. S. odorifera was consistently highly resistant to the crown canker phase of GSB in this study. C. grandis was the only species that was consistently resistant to both the foliar blight and crown canker phases of GSB. In all, 14 species from 12 genera were identified as new hosts of S. citrulli, information which could have future applications in resistance breeding and management of GSB on cucurbit crops (Table 8).

\section{Acknowledgments}

We thank V. B. DuBose, M. Rushton, and C. Conrad for technical assistance.

\section{Literature Cited}

Bala, G., and Hosein, F. 1986. Studies on gummy stem blight disease of cucurbits in Trinidad. Trop. Agric. Trinidad 63:195-197.

Brewer, M. T., Rath, M., and Li, H.-X. 2015. Genetic diversity and population structure of cucurbit gummy stem blight fungi based on microsatellite markers. Phytopathology 105:815-824.

Chester, F. D. 1891. Notes on three new or noteworthy diseases of plants. Bull. Torrey Bot. Club 18:371-374.

Chiu, W. F., and Walker, J. C. 1949. Physiology and pathogenicity of the cucurbit black-rot fungus. J. Agric. Res. 78:589-615.

Cohen, R., Pivonia, S., Crosby, K. M., and Martyn, R. D. 2012. Advances in the biology and management of Monosporascus vine decline and wilt of melons and other cucurbits. Hortic. Rev. (Am. Soc. Hortic. Sci.) 39:77-120.

Corlett, M. 1981. A taxonomic survey of some species of Didymella and Didymellalike species. Can. J. Bot. 59:2016-2042.

Crinò, P., Lo Bianco, C., Rouphael, Y., Colla, G., Saccardo, F., and Paratore, A. 2007. Evaluation of rootstock resistance to Fusarium wilt and gummy stem blight and effect on yield and quality of a grafted 'Inodorus' melon. HortScience 42:521-525.

dos Santos, G. R., Álvares da Silva Velloso Ferreira, M., Caldas de Pinho PessoaFilho, M. A., Ferreira, M. E., and Café-Filho, A. C. 2009. Host specificity and genetic diversity of didymella bryoniae from Cucurbitaceae in Brazil. J. Phytopathol. 157:265-273.

FAO. 2017. FAOSTAT. Online publication. http://www.fao.org/faostat

Farr, D. F., and Rossman, A. Y. 2017. Fungal Databases, U.S. National Fungus Collections. Online publication. United States Department of AgricultureAgricultural Research Service. https://nt.ars-grin.gov/fungaldatabases

Frantz, J. D., and Jahn, M. M. 2004. Five independent loci each control monogenic resistance to gummy stem blight in melon (Cucumis melo L.). Theor. Appl Genet. 108:1033-1038.

Fry, W. E. 1978. Quantification of general resistance of potato cultivars and fungicide effect for integrated control of potato late blight. Phytopathology 68:1650-1655.

Gonnermann, W., and Rabenhorst, L. 1869. Mycologia europaea: Abbildungen sämmtlicher Pilze Europas, Vol. 5/6 Pyrenomyceten, p. 15.

Greene, H. C. 1953. Notes on Wisconsin parasitic fungi. XIX Amer. Midl. Naturalist 50:501-508.

Grossenbacher, J. G. 1909. A Mycosphaerella wilt of melons. Pages 193-229 in N. Y. (Geneva) Agric. Exp. Stn. Tech. Bull. 9.

Holstein, N., and Renner, S. S. 2011. A dated phylogeny and collection records reveal repeated biome shifts in the African genus Coccinia (Cucurbitaceae) BMC Evol. Biol. 11:28.

Jensen, B. D., Massawe, A., and Swai, I. S. 2011. First report of gummy stem blight caused by Didymella bryoniae on watermelon and confirmation of the disease on pumpkin in Tanzania. Plant Dis. 95:768.

Jiang, N., Hu, F. Y., Ye, Y. F., Jiang, Sh. Y., and Huang, X. Y. 2015. First report of leaf spot caused by Stagonosporopsis cucurbitacearum on Luohanguo (Siraitia grosvenorii) in China. Plant Dis. 99:1645.

Keinath, A. P. 2000. Effect of protectant fungicide application schedules on gummy stem blight epidemics and marketable yield of watermelon. Plant Dis. 84:254-260.

Keinath, A. P. 2002. Survival of Didymella bryoniae in buried watermelon vines in South Carolina. Plant Dis. 38:32-38.

Keinath, A. P. 2008. Survival of Didymella bryoniae in infested muskmelon crowns in South Carolina. Plant Dis. 92:1223-1228.

Keinath, A. P. 2011. From native plants in central Europe to cultivated crops worldwide: The emergence of Didymella bryoniae as a cucurbit pathogen. HortScience 46:532-535.

Keinath, A. P. 2013. Diagnostic guide for gummy stem blight and black rot on cucurbits. Online publication. Plant Health Prog. doi.org/10.1094/PHP-20131024-01-DG

Keinath, A. P. 2014a. Differential susceptibility of nine cucurbit species to the foliar blight and crown canker phases of gummy stem blight. Plant Dis. 98:247-254.

Keinath, A. P. 2014b. Reproduction of Didymella bryoniae on nine species of cucurbits under field conditions. Plant Dis. 98:1379-1386.

Keinath, A. P. 2017. Gummy stem blight. Page 59 in: Compendium of Cucurbit Diseases and Pests, 2nd ed. A. P. Keinath, W. M. Wintermantel, and T. A Zitter, eds. American Phytopathological Society, St. Paul, MN.

Keinath, A. P., and Duthie, J. A. 1998. Yield and quality reductions in watermelon due to anthracnose, gummy stem blight, and black rot. Pages 77-90 in: Recent Research Developments in Plant Pathology, Vol. 2. Research Signpost, Trivandrum, India.

Keinath, A. P., Fillippelli, E. L., Baccari, G. V., and DuBose, V. B. 2010. Susceptibility of 15 cultivars of watermelon, melon, squash, pumpkin, and bottle gourd to gummy stem blight, 2009. Online publication. Plant Dis. Manage. Rep. 4:V120.

Keinath, A. P., and Hassell, R. L. 2014a. Control of Fusarium wilt of watermelon by grafting onto bottlegourd or interspecific hybrid squash despite colonization of rootstocks by Fusarium. Plant Dis. 98:255-266.

Keinath, A. P., and Hassell, R. L. 2014b. Suppression of Fusarium wilt caused by Fusarium oxysporum $\mathrm{f}$. sp. niveum race 2 on grafted triploid watermelon. Plant Dis. 98:1326-1332.

King, S. R., Davis, A. R., Liu, W., and Levi, A. 2008. Grafting for disease resistance. HortScience 43:1673-1676.

Kocyan, A., Zhang, L.-B., Schaefer, H., and Renner, S. S. 2007. A multi-locus chloroplast phylogeny for the Cucurbitaceae and its implications for character evolution and classification. Mol. Phylogenet. Evol. 44:553-577.

Lee, J.-M. 1994. Cultivation of grafted vegetables I. Current status, grafting methods, and benefits. HortScience 29:235-239.

Lou, L., Wang, H., Qian, C., Liu, J., Bai, Y., and Chen, J. 2013. Genetic mapping of gummy stem blight (Didymella bryoniae) resistance genes in Cucumis sativus-hystrix introgression lines. Euphytica 192:359-369.

Mendes, M. A. S., da Silva, V. L., Dianese, J. C., Ferreira, M. A. S. V., dos Santos, C. E. N., Gomes Neto, E., Urben, A. F., and Castro, C. 1998. Fungos em plantas no Brasil. Embrapa-SPI/Embrapa-Cenargen, Brasilia, Brazil.

Norton, J. D. 1979. Inheritance of resistance to gummy stem blight caused in watermelon. HortScience 14:630-632.

Prasad, K., and Norton, J. D. 1967. Inheritance of resistance to Mycosphaerella citrullina in muskmelon. Proc. Am. Soc. Hortic. Sci. 91:396-400.

Punithalingam, E., and Holliday, P. 1972. Didymella bryoniae. CMI Description of Pathogenic Fungi and Bacteria, No. 332. Commonwealth Mycological Institute, Kew, UK. 
Rennberger, G., Kousik, C. S., and Keinath, A. P. 2018. First Report of Powdery Mildew on Cucumis zambianus, Cucurbita digitata, and Melothria scabra Caused by Podosphaera xanthii in the United States. Plant Dis. 102:246.

Renner, S. S., and Pandey, A. K. 2013. The Cucurbitaceae of India: Accepted names, synonyms, geographic distribution and information on images and DNA sequences. PhytoKeys 20:53-118.

Robinson, R. W., and Decker-Walters, D. S. 1997. Cucurbits. CAB International, New York.

Saccardo, P. A. 1891. Didymella melonis. Syll. fung. addit. Vol. 1-4:86.

Santner, T. J., and Duffy, D. E. 1989. The Statistical Analysis of Discrete Data. Springer-Verlag, New York.

Schaefer, H., Heibl, C., and Renner, S. S. 2009. Gourds afloat: A dated phylogeny reveals an Asian origin of the gourd family (Cucurbitaceae) and numerous oversea dispersal events. Proc. R. Soc. B. 276:843-851.

Schaefer, H., and Renner, S. S. 2011. Phylogenetic relationships in the order Cucurbitales and a new classification of the gourd family (Cucurbitaceae). Taxon 60:122-138.

Schenck, N. C. 1968. Epidemiology of gummy stem blight (Mycosphaerella citrullina) on watermelon: Ascospore incidence and disease development. Phytopathology 58:1420-1422.

Shaner, G., and Finney, R. E. 1977. the effect of nitrogen fertilization on the expression of slow-mildewing resistance in Knox wheat. Phytopathology 67: 1051-1056.

Simpson, M. G. 2010. Plant Systematics, 2nd ed. Academic Press, Burlington, MA.

Sitterly, W. R. 1969. Effect of crop rotation on cucumber gummy stem blight. Plant Dis. Rep. 53:417-419.

Somai, B. M., Dean, R. A., Farnham, M. W., Zitter, T. A., and Keinath, A. P. 2002. Internal transcribed spacer regions 1 and 2 and random amplified polymorphic DNA analysis of Didymella bryoniae and related Phoma species isolated from cucurbits. Phytopathology 92:997-1004.

St. Amand, P. C., and Wehner, T. C. 2001. Heritability and genetic variance estimates for leaf and stem resistance to gummy stem blight in two cucumber populations. J. Am. Soc. Hortic. Sci. 126:90-94.

Stewart, J. E., Turner, A. N., and Brewer, M. T. 2015. Evolutionary history and variation in host range of three Stagonosporopsis species causing gummy stem blight of cucurbits. Fungal Biol. 119:370-382.

Svedelius, G. 1990. Effects of environmental factors and leaf age on growth and infectivity of Didymella bryoniae. Mycol. Res. 94:885-889.

Thies, J. A., Ariss, J. J., Hassel, R. L., Buckner, S., and Levi, A. 2015. Accessions of Citrullus lanatus var. citroides are valuable rootstocks for grafted watermelon in fields infested with root-knot nematodes. HortScience 50:4-8.
Thomas, A., Carbone, I., Lebeda, A., and Ojiambo, P. S. 2017. Virulence structure within the populations of Pseudoperonospora cubensis in the United States. Phytopathology 107:777-785.

Thomas, C. E., and Jourdain, E. L. 1992. Host effect on selection of virulence factors affecting sporulation of Pseudoperonospora cubensis. Plant Dis. 76 905-907.

van Steekelenburg, N. A. M. 1983. Epidemiological aspects of Didymella bryoniae, the cause of stem and fruit rot of cucumber. Neth. J. Plant. Pathol. 89:75-86.

Wako, T., Sakata, Y., Sugiyama, M., Ohara, T., Ishiuchi, D., and Kojima, A. 2002. Identification of melon accessions resistant to gummy stem blight and genetic analysis of the resistance using an efficient technique for seedling test. Acta Hortic. 588:161-164.

Wehner, T. C., and St. Amand, P. C. 1993. Field tests for cucumber resistance to gummy stem blight in North Carolina. HortScience 28:327-329.

Wiant, J. S. 1945. Mycosphaerella black rot of cucurbits. J. Agric. Res. 71:193-213.

Widrlechner, M. P., Kirkbride, J. H., Jr., Ghebretinsae, A. G., and Reitsma, K. R. 2008. Cucumis zambianus (Cucurbitaceae), a new species from northwestern Zambia. Syst. Bot. 33:732-738

Wolukau, J. N., Zhou, X., Li, Y., Zhang, Y., and Chen, J. 2007. Resistance to gummy stem blight in melon (Cucumis melo L.) germplasm and inheritance of resistance from plant introductions 157076, 420145, and 323498. HortScience 42:215-221.

Zhang, J. X., Bruton, B. D., Miller, M. E., and Isakeit, T. 1999. Relationship of developmental stage of cantaloupe fruit to black rot susceptibility and enzyme production by Didymella bryoniae. Plant Dis. 83:1025-1032.

Zhang, L.-B., Simmons, M. P., Kocyan, A., and Renner, S. S. 2006. Phylogeny of the Cucurbitales based on DNA sequences of nine loci from three genomes: Implications for morphological and sexual system evolution. Mol. Phylogenet. Evol. 39:305-322.

Zhang, S., Liu, S., Miao, H., Shi, Y., Wang, M., Wang, Y., Li, B., and Gu, X. 2017. Inheritance and QTL mapping of resistance to gummy stem blight in cucumber. Mol. Breed. 37:49.

Zitter, T. A. 2017. Black Rot. Page 92 in: Compendium of Cucurbit Diseases and Pests, 2nd ed. A. P. Keinath, W. M. Wintermantel, and T. A. Zitter, eds. American Phytopathological Society, St. Paul, MN.

Zúniga, T. L. 1999. Gummy stem blight (Didymella bryoniae) of cucurbits Pathogen characterization and inheritance of resistance in melon (Cucumis melo). Ph.D. dissertation, Department of Plant Pathology, Cornell University, Ithaca, NY.

Zúniga, T. L., Jantz, J. P., Zitter, T. A., and Jahn, M. M. 1999. Monogenic dominant resistance to gummy stem blight in two melon (Cucumis melo) Accessions. Plant Dis. 83:1105-1107. 